\title{
PERFORMANSI FISIOLOGIS UDANG VANAME, Litopenaeus vannamei YANG DIPELIHARA PADA MEDIA AIR TAWAR DENGAN APLIKASI KALIUM
}

\author{
Aan Fibro Widodo, Brata Pantjara, Noor Bimo Adhiyudanto, \\ dan Rachmansyah \\ Balai Riset Perikanan Budidaya Air Payau \\ Jl. Makmur Dg. Sitakka No. 129, Maros 90512, Sulawesi Selatan \\ E-mail: litkanta@indosat.net.id
}

(Naskah diterima: 21 Maret 2011; Disetujui publikasi: 12 Mei 2011)

\begin{abstract}
ABSTRAK
Kalium sangat penting bagi udang terutama yang dipelihara pada media air tawar. Kalium merupakan mineral mikro yang penting bagi udang terutama dalam menjaga keseimbangan elektrolit cairan tubuh, penghantaran impuls saraf, serta pembebasan tenaga yang berasal dari protein, lemak, dan karbohidrat pada proses metabolisme. Penelitian ini bertujuan untuk mengetahui performansi udang vaname, Litopenaeus vannamei, yang dipelihara pada media air tawar dengan aplikasi kalium. Penelitian dilakukan di Laboratorium Basah Balai Riset Perikanan Budidaya Air Payau, Maros. Hewan uji yang digunakan adalah udang vaname umur 62 hari dengan bobot awal rata- rata $5,80 \pm 0,02 \mathrm{~g}$. Penelitian dirancang dengan pola rancangan acak lengkap (RAL) yang terdiri atas 4 perlakuan dan 3 ulangan. Perlakuan yang diujikan adalah aplikasi $\mathrm{KCl}$ sebagai sumber kalium pada air tawar pengencer media bersalinitas 1- 0 ppt, masingmasing konsentrasi kalium pada perlakuan A, B, C, dan D secara berurutan adalah 25, 50, 75, dan $0 \mathrm{mg} / \mathrm{L}$ (kontrol). Sebelum penelitian berlangsung, udang diadaptasikan di air payau dengan salinitas 25 ppt selama 10 hari. Selanjutnya salinitas diturunkan sampai 1 ppt selama 3 hari, dilanjutkan pemeliharaan pada salinitas 0 ppt sampai akhir penelitian (30 hari). Peubah yang diamati adalah tingkat kerja osmotik, laju konsumsi oksigen, konsentrasi glukosa darah, sintasan, laju pertumbuhan bobot, dan panjang spesifik harian serta peubah kualitas air. Hasil penelitian menunjukkan bahwa aplikasi kalium 25- 75 mg/ L pada media pemeliharaan air tawar dapat meningkatkan kemampuan osmoregulasi dan mengurangi tingkat stres udang vaname sehingga dapat meningkatkan laju pertumbuhan dan sintasannya. Uji statistik terhadap tingkat kerja osmotik, tingkat konsumsi oksigen, dan konsentrasi glukosa darah berbeda nyata $(P<0,05)$ antar perlakuan, namun performansi fisiologis udang vaname terbaik dengan tingkat osmotik, laju konsumsi oksigen, dan konsentrasi glukosa darah terendah diperoleh pada perlakuan aplikasi kalium konsentrasi 50 mg/ L (optimum 55,05-56,43 mg/ L).
\end{abstract}

\section{KATA KUNCl: air tawar, kalsium, performansi fisiologis, udang vaname}

ABSTRACT: Physiological performance of white shrimp, Litopenaeus vannamei cultured in potassium-treated freshwater media. By: Aan Fibro Widodo, Brata Pantjara, Noor Bimo Adhiyudanto, and Rachmansyah

Potassium is essential for shrimp especially for those cultured in the freshwater aquaculture systems. Potassium is very crucial in maintaining the balance of electrolyte in the cell body, particularly in the process of nerve impulse delivery and 
releasing energy from protein, fat, and carbohydrate in the metabolic processes. This study was aimed to determine the performance of white shrimp (Litopenaeus vannamei) cultured in freshwater media treated with potassium. The research was conducted in the Wet Laboratory of the Institute for Coastal Aquaculture (RICA), Maros. Whiteleg shrimps of 62 days in age average and $5.80 \pm 0.02 \mathrm{~g}$ of initial weight average were used in the experiment. The study employed completely randomized design (RAL) which consisted of four treatments and three replications. The treatments were the application of $\mathrm{KCl}$ as the source of potassium into freshwater media of which the salinity was maintained at 1-0 ppt. The $\mathrm{KCl}$ addition as the treatments were 25, 50,75 , and $0 \mathrm{mg} / \mathrm{L}$ (control) arranged as treatment $A, B, C$, and $D$, respectively. The shrimp was firstly acclimatized in brackishwater media with the salinity of 25 ppt for 10 days before the treatment. Dilution of salinity was done by gradual addition of fresh water for 3 days which decreased the salinity from 25 ppt down to 1 ppt, and then the process was continued by rearing the shrimp for 30 days. The experiment variables measured were the level of osmotic activity, rate of oxygen consumption, blood glucose levels, survival rate, and weight gain and daily specific lenght. The results showed that the application of potassium with the concentration of 25-75 $\mathrm{mg} / \mathrm{L}$ into the freshwater media was visibly enhancing the shrimp's ability in controlling osmoregulation and reducing stress level which then led to the increase of growth and survival rate. The statistic analysis showed that the osmotic activity, oxygen consumption rate, and blood glucose levels in treated shrimp exibited a significant difference $(P<0.05)$ among the treatments. The best performing whiteleg shrimp in terms of osmoregulation level, oxygen consumption rate and the minimum blood glucose levels was found in the treatment with the application of $50 \mathrm{mg} / \mathrm{L}$ potassium (optimum of $55.05-56.43 \mathrm{mg} / \mathrm{L}$ potassium).

\section{KEYWORDS: fresh water, potassium, physiological performance, whiteleg shrimp}

\section{PENDAHULUAN}

Salah satu sumberdaya hayati perairan bernilai ekonomis penting dan telah dibudidayakan secara komersial adalah udang vaname (Litopenaeus vannamei). Pada penerapan teknologi sederhana sampai intensif dalam produksi udang vaname di wilayah tropis telah menunjukkan bahwa udang vaname memiliki keunggulan dibandingkan dengan jenis udang yang lain. Udang vaname pertumbuhannya lebih cepat, dapat mengisi semua kolom air sehingga dapat dibudidayakan dengan padat tebar yang tinggi, bersifat eurihalin, serta lebih tahan terhadap penyakit dan gangguan lingkungan (Poernomo, 2004).

Budidaya udang vaname di Indonesia umumnya hanya dilakukan di tambak, sementara untuk daerah yang jauh dari sumber air laut belum banyak dilakukan. Kendala utama yang dihadapi adalah terbatasnya ketersedian air laut untuk pemeliharaan (Taqwa et al., 2008). Selain itu, peningkatan salinitas yang cukup tinggi (40- 47 ppt) juga menjadi kendala dalam budidaya udang vaname di tambak pada musim kemarau (Hendradjat \& Mangampa,
2007). Budidaya udang vaname di air tawar merupakan salah satu solusi untuk mengatasi hal tersebut. Permasalahan selanjutnya yang muncul adalah rendahnya sintasan yang dihasilkan. Beberapa teknik aklimatisasi udang vaname pada media bersalinitas rendah telah dilaporkan meskipun sintasan yang diperoleh masih rendah (McGraw et al., 2002; Saoud et al., 2003). Tingkat mortalitas yang tinggi diduga disebabkan perubahan salinitas yang ekstrim. Perubahan salinitas menyebabkan laju osmoregulasi meningkat sehingga laju beban osmotik, konsumsi oksigen dan tingkat stres meningkat. Selain itu, dalam media air tawar, diduga udang mengalami defisiensi mineralmineral penting untuk sintasannya. Salah satu mineral yang perlu untuk ditambahkan adalah kalium. Berdasarkan hasil pengukuran laboratorium diketahui bahwa media air tawar (air sumur) yang digunakan memiliki konsentrasi kalium yang sangat rendah $(2,12$ mg/L), sedangkan Riley \& Chester (1971) menyatakan bahwa air laut bersalinitas $35 \mathrm{ppt}$ mengandung kalium sebesar $420 \mathrm{mg} / \mathrm{L}$. Defisiensi kalium disebut Hipokalemia, yaitu suatu keadaan di mana konsentrasi kalium 
dalam darah kurang dari 3,5 mEq/ L darah (Anonim, 2008).

McGraw \& Scarpa (2003) menyatakan bahwa aktivitas enzim pada krustase sangat tergantung pada konsentrasi kalium yang berperan dalam mempertahankan kondisi konstan hemolymp ketika terjadi fluktuasi salinitas. Kalium merupakan mineral mikro yang penting bagi udang. Di dalam tubuh, kalium biasanya bekerja sama dengan sodium (Na) dalam mengatur keseimbangan muatan elektrolit cairan tubuh (Anonim, 2008). Kalium juga penting dalam penghantaran impuls saraf, serta pembebasan tenaga yang berasal dari protein, lemak, dan karbohidrat pada proses metabolisme (Ningharmanto, 2009). Pengaruh penambahan kalium terhadap performansi pascalarva udang vaname pada masa aklimatisasi ke media bersalinitas rendah telah diteliti (Taqwa et al., 2008), namun implikasinya terhadap performansi udang vaname yang dipelihara di media air tawar belum banyak dilaporkan. Taqwa et al. (2008) melaporkan bahwa penambahan kalium sebanyak $25 \mathrm{mg} / \mathrm{L}$ pada air tawar pengencer (konsentrasi kalium media bersalinitas 2 ppt) menjadi $51 \mathrm{mg} / \mathrm{L}$ pada aklimatisasi pascalarva vaname selama 4 hari dapat menurunkan beban osmotik, pembelanjaan energi untuk metabolisme basal dan tingkat stres sehingga dapat meningkatkan sintasan pascalarva udang vaname.

Meskipun telah diketahui bahwa udang vaname bisa hidup pada kisaran salinitas yang luas, namun implikasi metabolisme dari kondisi tersebut belum banyak diketahui padahal informasi fisiologi yang berhubungan dengan laju osmoregulasi sangat dibutuhkan. Metabolisme respirasi, tingkat osmotik, dan tingkat stres tampaknya cukup tepat untuk mengukur pengeluaran energi udang vaname dalam kondisi tawar karena umumnya dianggap sebagai salah satu indikator terbaik aktivitas fisiologis umum individu, mengintegrasikan khususnya pertukaran energi yang diperlukan untuk regulasi osmotik. Oleh sebab itulah penambahan sumber kalium pada media pemeliharaan diharapkan dapat menunjang kebutuhan kalium sehingga dapat meningkatkan sintasan udang vaname yang dipelihara pada media air tawar. Penelitian ini bertujuan untuk mengetahui performansi fisiologis udang vaname dengan aplikasi kalium pada media pemeliharaan air tawar.

\section{BAHAN DAN METODE}

Penelitian dilaksanakan di Laboratorium Basah Balai Riset Perikanan Budidaya Air Payau (BRPBAP), Maros. Penelitian menggunakan wadah berupa akuarium fiberglass berukuran panjang, lebar dan tinggi masing- masing 50 $\mathrm{cm} \times 75 \mathrm{~cm} \times 60 \mathrm{~cm}$ berjumlah 12 buah. Akuarium masing- masing diisi air laut sebanyak $20 \mathrm{~L}$ dan diaerasi terus- menerus. Hewan uji yang digunakan adalah udang vaname umur 62 hari dengan bobot awal rata- rata 5,80 $\pm 0,02$ g. Udang vaname uji ditebar dengan kepadatan 5 ekor/akuarium yang dipelihara selama 30 hari. Sebelum ditebar ke wadah penelitian terlebih dahulu dilakukan penimbangan bobot dengan menggunakan timbangan elektrik berketelitian 0,01 g. Selama penelitian berlangsung udang diberi pakan komersial (pelet) dengan komposisi proksimat: lemak $(6,53 \%$ ), protein $(27,43 \%)$, serat kasar $(1,45 \%)$, dan abu (7,79\%) (Tahe, 2008). Pemberian dilakukan setiap hari sebesar $5 \%$ biomassa dengan frekuensi pemberian $3 \mathrm{kali} /$ hari yakni pada pukul 07.00, 12.00, dan 17.00.

Sumber air yang digunakan terdiri atas air laut bersalinitas $30 \mathrm{ppt}$. Stok air laut diambil dari perairan Teluk Awerange Kabupaten Barru, Sulawesi Selatan. Untuk mendapatkan media perlakuan sesuai dengan salinitas yang diinginkan maka dilakukan teknik pengenceran dengan air tawar yang bersumber dari air sumur. Pengenceran dilakukan dengan berpedoman pada rumus yang digunakan Anggoro (1992) sebagai berikut:

$$
\mathrm{S} 2=\frac{(\mathrm{a} \times \mathrm{S} 1)}{(n+a)}
$$

di mana:

$\mathrm{S} 2$ = Tingkat salinitas yang diinginkan (ppt)

S1 = Tingkat salinitas air laut yang akan diencerkan (ppt)

$\mathrm{a}=$ Volume air laut yang diencerkan (L)

$\mathrm{n}$ = Volume air tawar yang perlu ditambahkan (L)

Penelitian dirancang dengan pola rancangan acak lengkap (RAL) yang terdiri atas 4 perlakuan dan 3 ulangan. Perlakuan yang diujikan adalah aplikasi kalium pada air tawar pengencer media bersalinitas 1- 0 ppt. Masingmasing konsentrasi $\mathrm{KCl}$ pada perlakuan $\mathrm{A}, \mathrm{B}$, C dan D secara berurutan adalah 25, 50, 75, dan 0 mg/ L (kontrol) yang berdasarkan hasil laboratorium setara dengan konsentrasi kalium 
secara berurutan sebesar 10,$37 ; 20,55 ; 31,02$; dan $2,12 \mathrm{mg} / \mathrm{L}$. Sebelum penelitian berlangsung, udang diadaptasikan di air payau dengan salinitas 25 ppt selama 10 hari. Selanjutnya salinitas diturunkan sampai 1 ppt selama 3 hari, dilanjutkan pemeliharaan pada salinitas 0 ppt sampai akhir penelitian (30 hari). Air tawar yang digunakan sebelumnya telah ditambahkan dolomit $\left(\mathrm{CaMg}\left(\mathrm{CO}_{3}\right)_{2}\right)$ sebagai sumber kalsium sebanyak $50 \mathrm{mg} / \mathrm{L}$ dan perlakuan aplikasi $\mathrm{KCl}$ sebagai sumber kalium sesuai perlakuan. Persentase mineral yang terkandung di dalam dolomit $\left(\mathrm{CaMg}\left(\mathrm{CO}_{3}\right)_{2}\right)$ berdasarkan kemasan terdiri atas $\mathrm{MgO}(20 \%)$, $\mathrm{CaO}(30 \%)$, dan $\mathrm{H}_{2} \mathrm{O}(1 \%)$. Untuk menjaga kualitas air media penelitian, maka sisa- sisa pakan dan kotoran udang uji disipon setiap hari. Untuk mempertahankan salinitas media, maka dilakukan pengukuran salinitas pada setiap pagi dan sore sehari dengan menggunakan hand refraktometer. Jika terjadi peningkatan salinitas, maka dilakukan penambahan air tawar sampai salinitas media sesuai dengan perlakuan.

Peubah yang diamati adalah tingkat osmotik, laju konsumsi oksigen, konsentrasi glukosa darah, sintasan, laju pertumbuhan bobot dan panjang spesifik harian serta peubah kualitas air. Pengukuran tingkat osmotik, laju konsumsi oksigen, konsentrasi glukosa darah, dan peubah kualitas air dilakukan pada awal dan dan selanjutnya setiap 7 hari, sedangkan sintasan dan laju pertumbuhan diamati pada akhir penelitian. Wadah yang digunakan pada pengukuran tingkat konsumsi oksigen adalah chamberl bentik jar yakni alat yang terbuat dari kaca volume $1 \mathrm{~L}$ sebanyak 4 unit. Keseluruhan chamber/ bentik jar diinkubasikan selama 1 jam dalam wadah yang menggunakan air yang sama dengan media penelitian. Oksigen terlarut diukur dengan alat pengukur $\mathrm{O}_{2}$ (TPS ${ }^{\mathrm{TM}}$ Model WP- 82 DO meters). Data laju respirasi selama proses inkubasi diperoleh dari data loger yang merekam dinamika kandungan oksigen terlarut diukur setiap lima menit. Pada prinsipnya pengukuran ini menggunakan media air untuk mengetahui oksigen yang dikonsumsi/ digunakan oleh udang uji dengan mengurangkan oksigen terlarut awal dan akhir setelah diinkubasi selama 1 jam. Data tersebut menunjukkan total konsumsi oksigen oleh udang vaname. Selain merekam data kelarutan oksigen, data loger juga merekam secara otomatis nilai suhu dari media yang diukur.
Konsumsi oksigen dihitung berdasarkan formula Liao \& Huang (1975) sebagai berikut:

$$
\mathrm{OC}=\frac{\mathrm{V} \times\left(\mathrm{DO}_{\mathrm{to}}-\mathrm{DO}_{\mathrm{tn}}\right)}{\mathrm{W} \times \mathrm{T}}
$$

di mana:

$$
\begin{aligned}
\mathrm{OC}= & \text { Konsumsi oksigen }\left(\mathrm{mg} \mathrm{O}_{2} / \mathrm{g} / \mathrm{jam}\right) \\
\mathrm{V}= & \text { Volume air dalam wadah }(\mathrm{L}) \\
\mathrm{DO}_{\mathrm{to}}= & \text { Konsentrasi oksigen terlarut pada awal } \\
& \text { pengamatan }(\mathrm{mg} / \mathrm{L}) \\
\mathrm{Do}_{\mathrm{tn}}= & \text { Konsentrasi oksigen terlarut pada waktu } \\
& \mathrm{t}(\mathrm{mg} / \mathrm{L}) \\
\mathrm{W}= & \text { Bobot hewan uji }(\mathrm{g}) \\
\mathrm{T}= & \text { Periode pengamatan (jam) }
\end{aligned}
$$

Selanjutnya dilakukan pengambilan hemolymph udang vaname sebanyak 0,05 $\mathrm{mL}$ dengan spuit/disposible syringe $1 \mathrm{~mL}$ lalu dimasukkan ke dalam tube $1,5 \mathrm{~mL}$ yang sebelumnya telah ditambahkan Trisodium Citrate $\left(\mathrm{Na}_{3} \mathrm{C}_{6} \mathrm{H}_{5} \mathrm{O}_{7}\right) 3,8 \%$ sebagai antikoagulan. Hemolymph disentrifuge dengan kecepatan $3500 \mathrm{rpm}$ selama 10 menit pada suhu $4^{\circ} \mathrm{C}$ untuk memisahkan plasma dari sel darah. Plasma yang didapatkan digunakan untuk pengukuran tingkat kerja osmotik dan konsentrasi glukosa darah.

Tingkat kerja osmotik diukur dengan Fiske Model 210 Micro-Osmometer. Pengukuran konsentrasi glukosa darah menggunakan kit Glucose liquicolor (GOD-PAP Method Enzymatic Colorimetric Test for Glucose Method without Deproteinisation). Konsentrasi glukosa darah diukur dengan formula:

$$
C=100 \times \frac{\Delta \mathrm{A}_{\text {sampel }}}{\Delta \mathrm{A}_{\text {STD }}}
$$

di mana:

$$
\begin{array}{ll}
\mathrm{C} & =\text { Konsentrasi glukosa darah }(\mathrm{mg} / \mathrm{dl}) \\
\Delta \mathrm{A}_{\text {sampel }} & =\text { Absorbansi contoh } \\
\Delta \mathrm{A}_{\text {STD }} & =\text { Absorbansi larutan standar }
\end{array}
$$

Nilai absorbansi contoh dan Iarutan standar diukur pada panjang gelombang 500 $\mathrm{nm}$.

Sintasan dihitung dengan menggunakan formula Huynh \& Fotedar (2004), yaitu:

$$
\mathrm{SR}=\frac{\mathrm{N}_{\mathrm{t}}}{\mathrm{N}_{\mathrm{o}}} \times 100 \%
$$


di mana:

$\mathrm{SR}=$ Sintasan $(\%)$

$\mathrm{N}_{\mathrm{o}}$ = Jumlah hewan uji pada awal penelitian (ind.)

$\mathrm{N}_{\mathrm{t}}=$ Jumlah hewan uji yang hidup pada akhir penelitian (ind.)

Laju pertumbuhan bobot dan panjang spesifik harian dihitung dengan formula Spannhof (1983) dalam Teskeredzic et al. (1989) yaitu:

$$
\mathrm{SGR}=100\left[\left(\frac{\mathrm{Wt}}{\mathrm{Wo}}\right)^{1 / t}-1\right]
$$

di mana:

SGR = Laju pertumbuhan bobot spesifik harian $(\%$ hari)

Wo = Bobot rata-rata hewan uji pada awal penelitian (g)

Wt = Bobot rata- rata hewan uji pada waktu t (g)

$\mathrm{T}=$ Lama pemeliharaan (hari)

Selama penelitian berlangsung dilakukan pengukuran beberapa peubah fisika kimia air media pemeliharaan yaitu suhu, $\mathrm{pH}, \mathrm{NH}_{3}, \mathrm{NO}_{2}$, $\mathrm{NO}_{3}$, dan $\mathrm{PO}_{4}$. Data yang diperoleh dianalisis dengan menggunakan analisis ragam. Uji jarak ganda Duncan digunakan untuk membandingkan perbedaan antara perlakuan. Data hasil pengukuran dianalisis regresi dan korelasi untuk menentukan pola hubungan antara konsentrasi kalium dengan tingkat konsumsi oksigen, tingkat kerja osmotik, dan konsentrasi glukosa darah. Sebagai alat bantu untuk melaksanakan uji statistik tersebut digunakan paket program SPSS versi 16.0. dan Curve Expert Ver. 1.4. Data peubah kualitas air yang diperoleh selama penelitian dianalisis secara deskriptif berdasarkan kelayakan hidup udang vaname.

\section{HASIL DAN BAHASAN}

\section{Laju Osmoregulasi}

Tingkat osmotik setiap perlakuan disajikan pada Tabel 1. Berdasarkan analisis ragam, penambahan kalium berpengaruh nyata $(\mathrm{P}<0,05)$ terhadap tingkat osmotik udang vaname. Penambahan kalium sebanyak 50 $\mathrm{mg} / \mathrm{L}$ menghasilkan beban osmotik terendah yaitu sebesar 479,33 mOsm/ kg, disusul berturut-turut pada penambahan $75 \mathrm{mg} / \mathrm{L}$ (526,33 mOsm/ kg); 25 mg/ L (582,33 mOsm/ $\mathrm{kg}$ ), dan beban osmotik tertinggi diperoleh pada perlakuan kontrol $(0 \mathrm{mg} / \mathrm{L})$ sebesar $772,00 \mathrm{mOsm} / \mathrm{kg}$. Hal ini berarti, penambahan kalium pada media pemeliharaan mampu memperbaiki laju osmoregulasi udang vaname yang dipelihara pada media air tawar.

Dengan beban osmotik yang rendah maka energi yang diperoleh udang dari makanan yang digunakan untuk proses osmoregulasi akan lebih banyak digunakan untuk proses pertumbuhan dan mempertahankan sintasannya. Taqwa et al. (2008) melaporkan, penambahan kalium pada air tawar pengencer sebesar $25-50 \mathrm{mg} / \mathrm{L}$ menghasilkan tingkat kerja osmotik terendah (612- $659 \mathrm{mOsm} / \mathrm{LH}_{2} \mathrm{O}$ ). Hasil tersebut berbeda dengan tingkat kerja osmotik yang didapatkan pada penelitian ini, di mana tingkat kerja osmotik terendah didapatkan pada penambahan kalium pada air tawar pengencer sebesar $50 \mathrm{mg} / \mathrm{L}$ dengan tingkat kerja osmotik sebesar 479,33 mOsm/ $\mathrm{kg}$. Hal ini diduga karena sumber kalium yang digunakan berbeda. Pada penelitian Taqwa et al. (2008), kalium yang digunakan dalam bentuk $\mathrm{K}_{2} \mathrm{CO}_{3}$, sedangkan pada penelitian ini digunakan $\mathrm{KCl}$ sebagai sumber kalium $(50 \%$

Tabel 1. Tingkat osmotik setiap perlakuan selama penelitian

Table 1. Osmotic level of each treatment during the experiment

\begin{tabular}{lr}
$\begin{array}{l}\text { Perlakuan (penambahan KCl) } \\
\text { Treatment (addition of } \mathrm{KCl})\end{array}$ & $\begin{array}{r}\text { Tingkat osmotik } \\
\text { Osmotic level (mOs }\end{array}$ \\
\hline A $(25 \mathrm{mg} / \mathrm{L})$ & $582.33 \pm 1.65^{\mathrm{c}}$ \\
B $(50 \mathrm{mg} / \mathrm{L})$ & $479.33 \pm 2.70^{\mathrm{a}}$ \\
C $(75 \mathrm{mg} / \mathrm{L})$ & $526.33 \pm 3.60^{\mathrm{b}}$ \\
D $(0 \mathrm{mg} / \mathrm{L})$ & $772.00 \pm 1.42^{\mathrm{d}}$
\end{tabular}

Nilai yang diikuti superscript serupa dalam kolom yang sama tidak berbeda nyata $(p>0,05)$

Values followed by the same superscript in the same column are not significantly different $(P>0.05)$ 
$\mathrm{K}_{2} \mathrm{O}$ ). Selain itu, udang dipelihara di media air tawar, sehingga diduga konsentrasi kalium yang dibutuhkan vaname lebih besar karena konsentrasi media yang lebih rendah $(2,12$ $\mathrm{mg} / \mathrm{L}$ ). Ukuran hewan uji yang digunakan juga berbeda, di mana pada penelitian ini digunakan udang vaname umur 62 hari sedangkan pada penelitian Taqwa et al. (2008) digunakan $\mathrm{PL}_{7}$ sebagai hewan uji. Byod (1990) menyatakan kebutuhan udang akan oksigen berbeda- beda, bergantung kepada spesies, ukuran stadia, aktivitas, jenis kelamin, saat reproduksi, tingkat konsumsi pakan, suhu dan konsentrasi oksigen terlarut. Salah satu faktor yang mempengaruhi tingkat kerja osmotik adalah tingkat konsumsi oksigen dan tingkat stres. Jompa et al. (2009) melaporkan bahwa konsumsi oksigen udang pama akan semakin berkurang sejalan dengan pertambahan bobot tubuh.

Salinitas merupakan salah satu faktor abiotik penting yang mempengaruhi sintasan dan pertumbuhan organisme akuatik. Salinitas dapat memodifikasi peubah fisika dan kimia air menjadi satu kesatuan pengaruh yang berdampak osmotik pada osmoregulasi dan bioenergetik (Karim, 2007). Osmoregulasi merupakan upaya hewan air untuk mengontrol keseimbangan air dan ion antara di dalam tubuh dan lingkungannya melalui mekanisme pengaturan tekanan osmotik. Sifat osmotik air berasal dari seluruh elektrolit yang larut dalam air tersebut. Semakin tinggi salinitas, konsentrasi elektrolit makin besar, sehingga tekanan osmotiknya makin tinggi (Connaughey \& Zottoli, 1983). Sebaliknya jika salinitas menurun maka konsentrasi elektrolit juga rendah.

Kalium penting bagi udang karena membantu menjaga cairan tubuh dan elektrolit, menjaga keseimbangan dalam selsel tubuh dan membantu dalam pengaturan tekanan darah. Ion $\mathrm{K}^{+}$merupakan elektrolit intraselluler/kation yang mempengaruhi tekanan osmose selluler, dan dalam hubungannya dengan $\mathrm{Na}^{+}$dan $\mathrm{Cl}^{-}$di luar sel menyebabkan adanya potensial muatan dalam dinding sel yang memungkinkan terjadinya impuls syaraf, denyut jantung dan lain- Iain (Linder, 1992; Lucu \& Towle, 2003). Perubahan salinitas media akan berpengaruh pada osmolaritas media dan cairan tubuh (plasma) udang. Perbedaan osmolaritas media dan plasma udang yang disebabkan oleh perubahan salinitas akan menentukan tingkat kerja osmotik (beban osmotik) udang. Ketika terjadi perubahan salinitas lingkungan, energi digunakan untuk mengubah konsentrasi cairan tubuh sesuai dengan lingkungan.

Penurunan laju konsumsi oksigen berdasarkan peningkatan bobot tubuh dapat dipahami karena pada saat udang berukuran kecil/muda kebutuhan oksigen untuk respirasi banyak digunakan untuk berbagai kepentingan, selain untuk metabolisme sendiri juga untuk kepentingan pertumbuhan sel, ganti kulit, dan lain- lain sedangkan untuk udang dewasa/ ukuran lebih besar tidak sebanyak seperti pada udang muda karena lebih untuk pertahanan diri (maintenance). Hasil yang berbeda juga didapatkan pada hasil pengukuran laju konsumsi oksigen dan konsentrasi glukosa darah.

Hasil analisis regresi mengenai hubungan faktor konsentrasi kalium dan tingkat kerja osmotik udang vaname selama penelitian menunjukkan hubungan kuadratik (Gambar 1). Hubungan tersebut digambarkan dengan persamaan sebagai berikut:

$$
Y=775,167-10,460 X+0,095 X^{2}
$$

Persamaan regresi menunjukkan bahwa konsentrasi kalium berkorelasi kuat dengan tingkat kerja osmotik udang vaname dengan $r_{x y}=0,996, r^{2}=0,991$, dan $r^{2}$ disesuaikan (adjusted $\left.r^{2}\right)=0,989$. Hal ini berarti sebesar $98,9 \%$ tingkat konsumsi oksigen udang vaname dapat diprediksi oleh konsentrasi kalium dan sisanya 1,1\%dapat diprediksi oleh faktor lainnya. Dari persamaan regresi didapatkan konsentrasi kalium optimum, yaitu pada konsentrasi 55,05 $\mathrm{mg} / \mathrm{L}$. Penambahan kalium sebanyak 55,05 $\mathrm{mg} / \mathrm{L}$ menghasilkan beban osmotik minimum yaitu sebesar 209,80 mOsm/ kg, setelah itu beban osmotik meningkat meskipun konsentrasi kalium ditingkatkan.

\section{Laju Konsumsi Oksigen}

Laju konsumsi oksigen setiap perlakuan disajikan pada Tabel 2. Berdasarkan analisis ragam, penambahan kalium berpengaruh nyata $(P<0,05)$ terhadap laju konsumsi oksigen udang vaname yang dipelihara pada media air tawar. Konsumsi oksigen terendah dijumpai pada perlakuan B (50 mg/L): 0,44 mg $\mathrm{O}_{2} / \mathrm{g} / \mathrm{jam}$, disusul perlakuan $\mathrm{C}$ (75 mg/ L): 0,53 $\mathrm{mg} \mathrm{O}_{2} / \mathrm{g} /$ jam, perlakuan $\mathrm{A}(25 \mathrm{mg} / \mathrm{L}): 0,63 \mathrm{mg} \mathrm{O} / \mathrm{g} / \mathrm{jam}$, dan tertinggi pada kontrol (0 mg/ L): 0,85 mg $\mathrm{O}_{2} / \mathrm{g} / \mathrm{jam}$. 


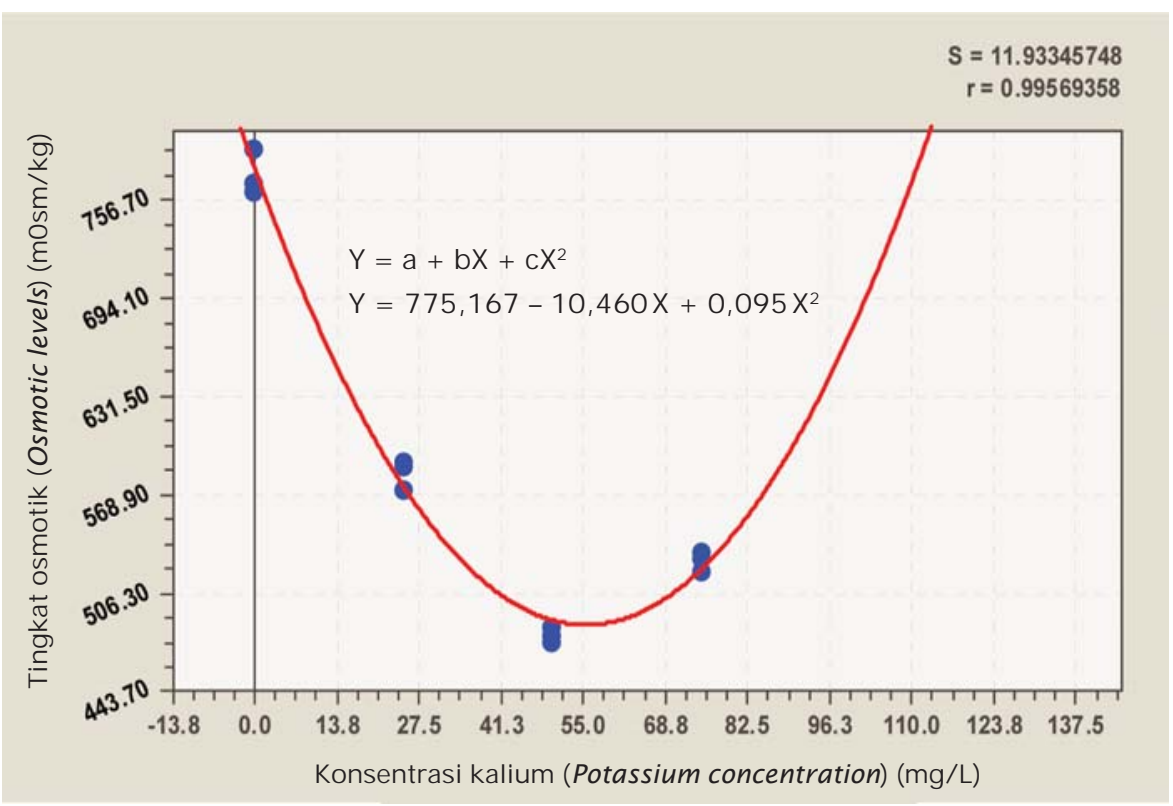

Gambar 1. Hubungan antara konsentrasi kalium dengan tingkat kerja osmotik udang vaname selama penelitian

Figure 1. Relationship between potassium concentration and osmotic activity in whiteleg shrimp for each treatment during the experiment

Tabel 2. Laju konsumsi oksigen setiap perlakuan selama penelitian

Table 2. Oxygen consumption rate for each treatment during the experiment

\begin{tabular}{lc}
\hline $\begin{array}{c}\text { Perlakuan (penambahan } \mathrm{KCl}) \\
\text { Treatment (addition of } \mathrm{KCl})\end{array}$ & $\begin{array}{c}\text { Laju konsumsi oksigen } \\
\text { Consumption oxygen rate } \\
\left(\mathbf{m g ~} \mathbf{0}_{2} / \mathbf{~ g} / \mathbf{j a m}\right)\end{array}$ \\
\hline $\mathrm{A}(25 \mathrm{mg} / \mathrm{L})$ & $0.63 \pm 0.028^{\mathrm{c}}$ \\
$\mathrm{B}(50 \mathrm{mg} / \mathrm{L})$ & $0.44 \pm 0.048^{\mathrm{a}}$ \\
$\mathrm{C}(75 \mathrm{mg} / \mathrm{L})$ & $0.53 \pm 0.024^{\mathrm{b}}$ \\
$\mathrm{D}(0 \mathrm{mg} / \mathrm{L})$ & $0.85 \pm 0.012^{\mathrm{d}}$ \\
\hline
\end{tabular}

Nilai yang diikuti superscript serupa dalam kolom yang sama tidak berbeda nyata (values followed by the same superscript in the same column are not significantly different) $(\mathrm{P}>0.05)$

Dalam sistem biologis, oksigen umumnya ditranslokasi oleh difusi sederhana, diikuti oleh gradien yang terdiri atas produksi dan konsumsi oksigen (Waser \& Heisler, 2004). Perubahan salinitas secara ekstrem dapat meningkatkan laju metabolisme udang yang memicu pergerakan pernafasan sehingga meningkatkan konsumsi oksigen dan laju pembelanjaan energi. Kondisi seperti ini akan mungkin memberikan pengaruh yang signifikan pada kehidupan krustase, terutama di tambak pembesaran. Udang umumnya dapat mengalami hypoxia atau bahkan anoxic, karena terganggunya proses respirasi organisme dan dekomposisi bahan organik akumulasi dari sisa pakan yang tidak dikonsumsi dan kotoran, terutama pada malam hari, dan kondisi hypoxia ini dapat mengancam 
kehidupan udang (Cheng et al., 2003). Hypoxia yaitu menurunnya kemampuan udang dalam mengambil oksigen (Kusmini et al., 2006) sehingga menghambat kinerja fisiologis normal udang, mengurangi frekuensi ganti kulit, menghambat pertumbuhan dan bahkan menyebabkan kematian (Allan \& Magurire, 1991).

Untuk mempertahankan homeostasis fisiologis sebagai respon terhadap kondisi lingkungan tidak menguntungkan, setiap jenis krustase telah mengembangkan sendiri mekanisme adaptif spesifik, termasuk perilaku dan tanggapan fisiologis, untuk mengatasi fluktuasi oksigen terlarut dari medium atau bahkan kondisi hypoxia. Respon adaptif untuk hypoxia termasuk pengurangan tingkat metabolisme (Hill et al., 1991), dan modifikasi dari keseimbangan asam- basa hemolymph, kapasitas mengikat hemocyanin, oxyhemocyanin protein, hemolymph osmolalitas, dan konsentrasi ion (Charmantier et al., 1994; Morris \& Butler, 1996; Chen \& Kou, 1998). Hiperventilasi akibat hypoxia tidak hanya meningkatkan aliran air di atas permukaan insang untuk meningkatkan pengambilan oksigen, tetapi juga meningkatkan ekskresi
$\mathrm{CO}_{2}$ dari hemolymph, yang menyebabkan meningkatnya pH darah (Morris \& Butler, 1996).

Menurut Hepher \& Pruginin (1981), bahwa tingkat kelarutan oksigen dipengaruhi oleh laju produksi oksigen melalui fotosintesis, laju transfer oksigen dari udara ke dalam air dan laju konsumsi oksigen karena respirasi, serta dipengaruhi oleh suhu dan salinitas (Boyd, 1990). Kebutuhan udang akan oksigen berbeda- beda, bergantung kepada spesies, ukuran stadia, aktivitas, jenis kelamin, saat reproduksi, tingkat konsumsi pakan, suhu, dan konsentrasi oksigen terlarut. Hal serupa juga dilaporkan oleh Batara (2004), bahwa tingkat konsumsi oksigen udang antara lain bergantung pada ukuran/stadia udang (internal) dan status makan (eksternal).

Hasil analisis regresi mengenai hubungan faktor konsentrasi kalium dan tingkat konsumsi oksigen udang vaname menunjukkan hubungan kuadratik (Gambar 2). Hubungan tersebut dapat digambarkan sebagai berikut:

$$
Y=0,8596-0,0137 X+0,000122 X^{2}
$$

Persamaan regresi menunjukkan bahwa faktor konsentrasi kalium berkorelasi kuat

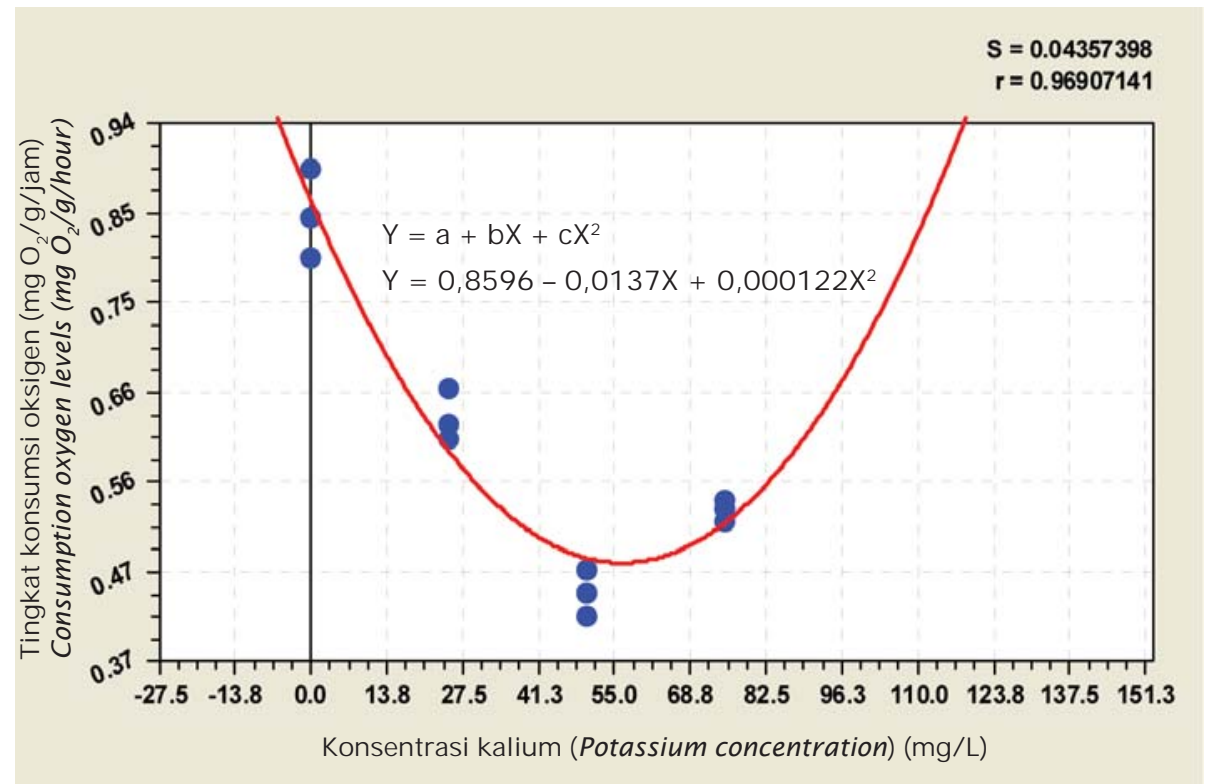

Gambar 2. Hubungan antara konsentrasi kalium dengan laju konsumsi oksigen udang vaname selama penelitian

Figure 2. Relationship between potassium concentration and oxygen consumption level in whiteleg shrimp for each treatment during the experiment 
Tabel 3. Konsentrasi kelarutan oksigen dan konsekuensinya terhadap organisme akuatik Table 3. Dissolve oxygen concentration and its consequences for aquatic organisms

\section{$1.0 \mathrm{mg} / \mathrm{L}$}

- Sangat mematikan (75-90\% pada beberapa ikan: pipe fish, winter flounder, summer flounder, Atlantic menhaden

Highly Lethal (75-90\%) in fishes: pipe fish, winter flounder, summer flounder, Atlantic menhaden

- Mematikan ( $25 \%$ pada tiga ikan tambahan: windowpane flounder, tautog, fourspine stickleback

Lethal ( 25\%) in three additional fishes: windowpane flounder, tautog, fourspine stickleback

- Peningkatan daya mematikan (50\% pada yuwanae krustase: Americ an lobster, sand shrimp, grass shrimp Increased lethality (50\%) in yuwanae crustaceans: American lobster, sand shrimp, grass shrimp

\section{$1.5 \mathrm{mg} / \mathrm{L}$}

- Mematikan pada beberapa ikan: pipe fish, $50 \%$ winter flounder, 35\%; summer flounder, 25\%; Atlantic menhaden, $20 \%$

Lethal for some fishes: pipe fish, 50\%; winter flounder, 35\% summer flounder, 25\% Atlantic menhaden, 20\%

- Ambang lethal pada beberapa yuwana krustase: American lobster, sand shrimp, grass shrimp

Lethal threshold for some juvenile crustaceans: American lobster, sand shrimp, grass shrimp

$2.0 \mathrm{mg} / \mathrm{L}$

- Pertumbuhan menurun ( $50 \%$ pada yuwanae summer flounder and yuwanae grass shrimp

Reduced growth ( 50\%) in juvenile summer flounder and yuwanae grass shrimp

- Oksigen terlarut terendah aman bagi kelangsungan hidup beberapa yuwana ikan dan krustase

Lowest safe dissolved oxygen for survival of juvenile of several fishes and crustaceans

$2.5 \mathrm{mg} / \mathrm{L}$

- Ambang lethal (15\% untuk larva planktonik krustase yang Lethality threshold (15\%) for the less sensitive planktonic larvae of crustaceans

- Penurunan pertumbuhan $(25 \%$ pada yuwana udang rumput dan summer flounder; 50\%pada Americ an lobster

Reduced growth (25\%) in juvenile of grass shrimp and summer flounder; $50 \%$ in American lobster

- Spesies tambahan yang hidup di dasar menunjukkan menghindari oksigen terlarut rendah

Additional species of bottom-living fishes avoid low dissolved oxygen area 
Tabel 3 Ianjutan (Table 3 continued)

\begin{tabular}{|c|c|}
\hline \multirow[t]{7}{*}{$3.0 \mathrm{mg} / \mathrm{L}$} & $\begin{array}{l}\text { - Lethal lebih tinggi }(\sim 75 \% \text { diantaranya yang sensitif adalah } \\
\text { larva kepiting planktonik }\end{array}$ \\
\hline & $\begin{array}{l}\text { Greater lethality ( } 75 \%) \text { among the most sensitive } \\
\text { planktonic crab larvae }\end{array}$ \\
\hline & $\begin{array}{l}\text { - Penurunan pertumbuhan ( } 50 \% \text { pada yang lain, sedikit pada } \\
\text { larva kepiting planktonik sensitif }\end{array}$ \\
\hline & Reduced growth (50\%) in other, less sensitive planktonic \\
\hline & - Penurunan pertumbuhan hingga 30 \%pada yuwanae \\
\hline & $\begin{array}{l}\text { - Ikan yang hidup di dasar mulai menunjukkan menghindari } \\
\text { oksigen terlarut rendah }\end{array}$ \\
\hline & $\begin{array}{l}\text { Bottom-living fishes begin to show low dissolved oxygen } \\
\text { avoidance behavior }\end{array}$ \\
\hline \multirow[t]{2}{*}{$4.0 \mathrm{mg} / \mathrm{L}$} & $\begin{array}{l}\text { - Dapat menurunkan sintasan (30 \% larva planktonik sangat } \\
\text { sensitif }\end{array}$ \\
\hline & $\begin{array}{l}\text { May reduce survival (30\%) of very sensitive planktonic } \\
\text { larvae of some crabs }\end{array}$ \\
\hline $5,0 \mathrm{mg} / \mathrm{L}$ atau lebih besar & - Beberapa efek samping yang diharapkan. \\
\hline 5.0 mg/L or greater & Fewadverse effects expected \\
\hline
\end{tabular}

Sumber: Zimmer (1996)

dengan tingkat konsumsi oksigen udang vaname dengan $r_{x y}=0,969, r^{2}=0,939$, dan $r^{2}$ disesuaikan (adjusted $\left.r^{2}\right)=0,926$. Hal ini berarti bahwa 92,6\%tingkat konsumsi oksigen udang vaname dapat diprediksi oleh konsentrasi kalium dan sisanya 7,4\%dapat diprediksi oleh faktor lainnya. Dari persamaan regresi didapatkan konsentrasi kalium optimum, yaitu pada konsentrasi 56,14 mg/ L. Penambahan kalium sebanyak 56,14 mg/ L menghasilkan laju konsumsi oksigen minimum yaitu sebesar 0,10 $\mathrm{mg} \mathrm{O}_{2} / \mathrm{g} / \mathrm{jam}$, setelah itu laju konsumsi oksigen meningkat meskipun konsentrasi kalium ditingkatkan.

Kisaran laju konsumsi oksigen yang diperoleh selama penelitian adalah 0,44-0,85 $\mathrm{mg} / \mathrm{g} / \mathrm{jam}$ dari udang vaname dengan bobot tubuh 5,80 $00,02 \mathrm{~g}$ dengan korelasi kuadratik. Kisaran kelarutan oksigen pada media yang digunakan pada saat awal pengukuran adalah 5,17-6,31 mg/ L dan setelah 1 jam pengukuran berkisar 0,78-2,76 mg/ $\mathrm{L}$ dan di mana kontrol 4 $\mathrm{mg} / \mathrm{L}$. Jika dibandingkan dengan konsentrasi kelarutan oksigen hasil penelitian Zimmer (1996), oksigen terlarut media masih memung- kinkan dan sangat mendukung kehidupan udang vaname, namun setelah 1 jam kemudian kelarutan oksigen sudah mencapai daya letal yang tinggi dan bisa menyebabkan kematian (Tabel 3).

\section{Konsentrasi Glukosa Darah}

Konsentrasi glukosa darah setiap perlakuan disajikan pada Tabel 4. Hasil analisis ragam menunjukkan bahwa penambahan kalium berpengaruh nyata $(P<0,05)$ terhadap konsentrasi glukosa darah udang vaname yang dipelihara pada media air tawar. Pada Tabel 4 dapat dilihat konsentrasi glukosa darah terendah diperoleh pada penambahan kalium sebanyak $50 \mathrm{mg} / \mathrm{L}$ yaitu sebesar 87,01 $\mathrm{mg} / \mathrm{dL}$ dan tertinggi pada perlakuan kontrol tanpa penambahan kalium yaitu sebesar $135,36 \mathrm{mg} / \mathrm{dL}$. Penambahan kalium sebesar 25 dan 75 mg/ L masing- masing menghasilkan konsentrasi glukosa darah sebesar 106,39 $\mathrm{mg} / \mathrm{dL}$ dan 96,27 mg/ dL.

Hasil penelitian ini menunjukkan bahwa kisaran konsentrasi glukosa udang vaname masih berada dalam kisaran normal. Jika 
Tabel 4. Konsentrasi glukosa darah setiap perlakuan selama penelitian

Table 4. Blood glucose content of shrimp in each treatment during the experiment

\begin{tabular}{lc}
\hline $\begin{array}{l}\text { Perlakuan (Penambahan } \mathrm{KCl}) \\
\text { Treatment (Addition of } \mathrm{KCl})\end{array}$ & $\begin{array}{c}\text { Konsentrasi glukosa darah } \\
\text { Blood glucose content (mg/ dI) }\end{array}$ \\
\hline A (25 mg/ L) & $106.39 \pm 4.595^{\mathrm{c}}$ \\
B (50 mg/ L) & $87.01 \pm 2.563^{\mathrm{a}}$ \\
C (75 mg/ L) & $96.27 \pm 2.475^{\mathrm{b}}$ \\
D (0 mg/ L) & $135.36 \pm 4.0368^{\mathrm{d}}$ \\
\hline
\end{tabular}

Nilai yang diikuti superscript serupa dalam kolom yang sama tidak berbeda nyata (values followed by the same superscript in the same column are not significantly different ) $(\mathrm{P}>0.05)$

konsentrasi glukosa hemolymp melebihi 150 $\mathrm{mg} / \mathrm{dL}$ mengindikasikan udang tersebut membutuhkan energi yang lebih tinggi pada saat ganti kulit dan dalam proses mempertahankan homeostasis konsentrasi glukosa yang meningkat (tinggi) dalam hemolymp itu sendiri (Cuzon et al., 2004). Perubahan lingkungan yang ekstrim menyebabkan udang rentan terhadap stres sehingga konsentrasi glukosa dalam hemolymp meningkat.

Stres merupakan suatu respon non spesifik pada tubuh terhadap banyak kebutuhan akibat paparan dari stresor. Stres juga dianggap sebagai upaya mempertahankan stabilitas lingkungan internal melalui perubahan berupa proses adaptif aktif melalui produksi berbagai macam mediator seperti steroid adrenal, katekolamin, sitokin, mediator jaringan, dan gen (McEwen, 1998). Stres pada udang dapat disebabkan oleh berbagai faktor biologis, kimia dan faktor fisik, dimana salinitas adalah salah satu yang paling signifikan. Untuk mempertahankan homeostasis fisiologis sebagai respon terhadap kondisi lingkungan tidak menguntungkan, setiap jenis krustase telah mengembangkan sendiri mekanisme adaptif spesifik, termasuk perilaku dan tanggapan fisiologis. Pada ikan, respon stres ditandai oleh rangsangan dari hipotalamus, menyebabkan aktivasi dari sistem neuro-endokrin dan perubahan metabolik yang dirancang untuk meningkatkan toleransi organisme terhadap perubahan lingkungan (Pickering, 1992; Wendelaar, 1997). Respon primer terhadap perubahan salinitas berhubungan dengan respon dari sistem endokrin dan pelepasan hormon stres (seperti kortisol dan katekolamin) ke dalam aliran darah, dan tanggapan sekunder terjadi sebagai akibat langsung dari pelepasan hormon- hormon (termasuk perubahan kimia dalam darah dan jaringan) (Lowe \& Davison, 2005).

Peningkatan konsentrasi glukosa darah atau hiperglikemia, umumnya dianggap sebagai indikator utama terjadinya stres pada ikan (Barton, 1997; Begg \& Pankhurst, 2004). Pada vertebrata, elevasi glukosa darah disebabkan oleh 'aksi dan fungsi' katekolamin sebagai sumber asupan energi (kalori) untuk meningkatkan/menurunkan laju reaksi (Pottinger et al., 2000). Katekolamin, seperti adrenalin, proses fosforilasinya berlangsung cepat menyebabkan glikogenolisis dengan mengaktifkan fosforilase sehingga terjadi glukoneogenesis (Vijayan \& Moon, 1992), dengan sumber utama glikogen di hati dan otot (Wedemeyer et al., 1990). Glukoneogenesis akan terjadi ketika persedian glikogen berkurang. Peningkatan tingkat sirkulasi adrenalin cepat dan sementara (Wells \& Weber, 1990), dan akan terjadi hiperglikemia. Kortikosteroid hormon kortisol juga telah dilaporkan sebagai penyebab hiperglikemia pada ikan (Pickering \& Pottinger, 1995; Vijayan et al., 1997; Mommsen et al., 1999; Begg \& Pankhurst, 2004). Hal ini diduga disebabkan karena proses glukoneogenesis (Vijayan et al., 1991). Kortisol berperan dalam mengendalikan beberapa proses fisiologis seperti perantara metabolisme, regulasi ionik dan osmotik, pertumbuhan, stres, dan fungsi kekebalan tubuh (Wendelaar, 1997; Mommsen et al., 1999). Pelepasan kortisol lebih lambat dibandingkan dengan pelepasan katekolamin, dan dampaknya lebih berkepanjangan (Gamperl et al., 1994; Waring et al., 1996). 


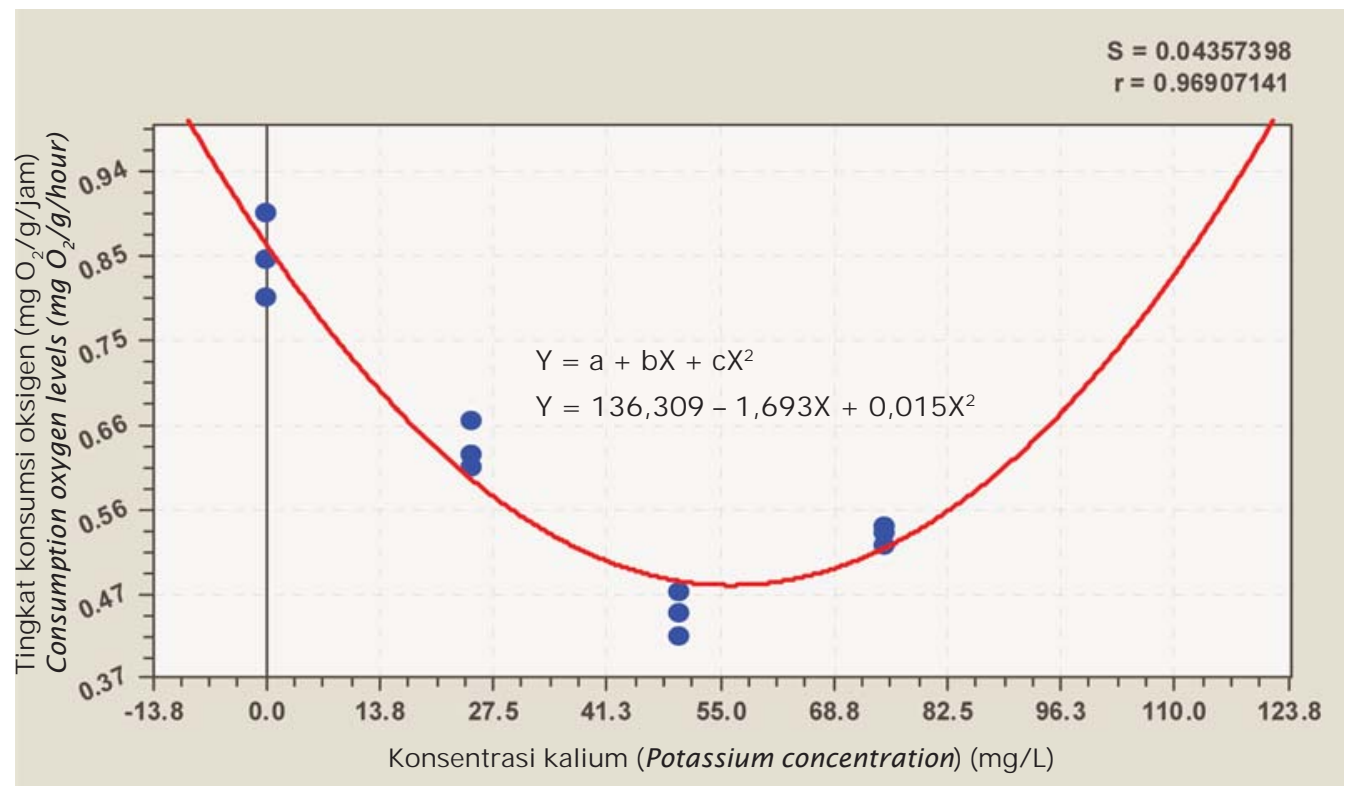

Gambar 3. Hubungan antara konsentrasi kalium dengan konsentrasi glukosa darah udang vaname selama penelitian

Figure 3. Relationship between potassium concentration and blood glucose content in white shrimp for each treatment during the experiment

Dengan asupan kalium yang diberikan diharapkan dapat membantu meningkatkan kepekaan hormon insulin terhadap glukosa darah, sehingga transportasi glukosa ke dalam sel menjadi lebih lancar dan tentunya metabolisme sel juga akan menjadi lebih lancar, dan implikasinya dapat menurunkan konsentrasi glokosa darah udang vaname.

Hasil analisis regresi mengenai hubungan faktor konsentrasi kalium dan konsentrasi glukosa darah udang vaname menunjukkan hubungan kuadratik (Gambar 3). Hubungan tersebut dapat digambarkan sebagai berikut:

$$
Y=136,309-1,693 X+0,015 X^{2}
$$

Persamaan regresi menunjukkan bahwa faktor konsentrasi kalium berkorelasi positif dengan tingkat konsumsi oksigen udang vaname dengan $r_{x y}=0,969, r^{2}=0,962$, dan $r^{2}$ disesuaikan (adjusted $r^{2}$ ) $=0,953$. Hal ini berarti bahwa 95,3\%konsentrasi glukosa darah udang vaname dapat diprediksi oleh konsentrasi kalium dan sisanya 4,7\%dapat diprediksi oleh faktor lainnya. Dari persamaan regresi didapatkan konsentrasi kalium optimum, yaitu pada konsentrasi $56,43 \mathrm{mg} / \mathrm{L}$. Penambahan kalium sebanyak 56,43 mg/ L menghasilkan konsentrasi glukosa darah minimum yaitu sebesar $42,47 \mathrm{mg} / \mathrm{dL}$, setelah itu konsentrasi glukosa darah meningkat meskipun konsentrasi kalium ditingkatkan.

\section{Sintasan dan Laju Pertumbuhan}

Pada penelitian didapatkan sintasan yang tidak berbeda nyata antar perlakuan $(P>0,05)$ yaitu sintasan sebesar $100 \%$ untuk semua perlakuan. Hal ini disebabkan karena pemeliharaan diusahakan sebaik mungkin, kualitas air berada pada kondisi optimal untuk kehidupan udang vaname, serta jumlah pakan yang cukup untuk menyuplai energi untuk kehidupan udang vaname. Analisis Iaju pertumbuhan bobot dan panjang spesifik harian antar perlakuan juga memperlihatkan perbedaan yang tidak nyata $(P>0,05)$. Laju pertumbuhan bobot harian berkisar antara 2,07$2,82 \pm 2,06$ dan laju pertumbuhan panjang harian berkisar antara 19,70-24,60 $\pm 16,49$. Hal diduga disebabkan karena selang waktu pemeliharaan yang relatif singkat (30 hari) sehingga laju pertumbuhan yang didapatkan tidak nyata antar perlakuan (Tabel 5).

Proses osmoregulasi yang lebih baik mengakibatkan energi yang diperoleh dari 
Tabel 5. Sintasan dan laju pertumbuhan harian udang vaname (Litopenaeus vannamei) setiap perlakuan selama penelitian

Table 5. Survival rate and daily growth rate of whiteleg shrimp (Litopenaeus vannamei) for each treatment during the experiment

\begin{tabular}{cccc}
\hline $\begin{array}{c}\text { Perlakuan } \\
\text { (Penambahan KCl) } \\
\text { Treatment }\end{array}$ & $\begin{array}{c}\text { Sintasan } \\
\text { Survival rate } \\
\text { (\%) }\end{array}$ & $\begin{array}{c}\text { Laju pertumbuhan } \\
\text { bobot harian spesifik } \\
\text { Daily weight growth } \\
\text { rate (\%) }\end{array}$ & $\begin{array}{c}\text { Laju pertumbuhan } \\
\text { panjang harian spesifik } \\
\text { Daily lenght growth } \\
\text { rate (\%) }\end{array}$ \\
\hline A $(25 \mathrm{mg} / \mathrm{L})$ & $100 \pm 0.00^{\mathrm{a}}$ & $2.73 \pm 2.06^{\mathrm{a}}$ & $23.56 \pm 12.58^{\mathrm{a}}$ \\
$\mathrm{B}(50 \mathrm{mg} / \mathrm{L})$ & $100 \pm 0.00^{\mathrm{a}}$ & $2.82 \pm 2.06^{\mathrm{a}}$ & $24.60 \pm 16.49^{\mathrm{a}}$ \\
$\mathrm{C}(75 \mathrm{mg} / \mathrm{L})$ & $100 \pm 0.00^{\mathrm{a}}$ & $2.30 \pm 0.67^{\mathrm{a}}$ & $24.06 \pm 7.27^{\mathrm{a}}$ \\
$\mathrm{K}(0 \mathrm{mg} / \mathrm{L})$ & $100 \pm 0.00^{\mathrm{a}}$ & $2.07 \pm 1.71^{\mathrm{a}}$ & $19.70 \pm 12.49^{\mathrm{a}}$ \\
\hline
\end{tabular}

Nilai yang diikuti superscript serupa dalam kolom yang sama tidak berbeda nyata Values followed by the same superscript in the same column are not significantly different $(P>0.05)$

makanan dimanfaatkan secara efisien untuk pertumbuhan. Hal ini terlihat pada laju pertumbuhan bobot dan panjang harian yang lebih rendah pada perlakuan kontrol yaitu tanpa aplikasi kalium pada media pemeliharaan dibandingkan dengan perlakuan A, B, dan C. Ion $\mathrm{K}^{+}$berperan dalam meningkatkan kemampuan osmoregulasi udang yang dipelihara pada media air tawar. Hal ini sangat berpengaruh terhadap proses metabolisme udang yang dapat berpengaruh pada tingkat pembelanjaan energi. Oleh sebab itu, pertumbuhan udang yang maksimum hanya dapat dihasilkan apabila penggunaan energi untuk metabolisme dapat diminimalisir. Pada kondisi hipoosmotik atau hiperosmotik, udang melakukan kerja osmotik yang tinggi sebagai respon fisiologis untuk mempertahankan lingkungan internalnya. Hal ini menyebabkan terjadinya peningkatan konsumsi oksigen, penurunan aktivitas makan dan aktivitas rutinitas (Kumlu et al., 2001).

Proses adaptasi terhadap kondisi salinitas dilakukan melalui proses osmoregulasi. Untuk organisme akuatik, proses tersebut digunakan sebagai langkah untuk menyeimbangkan tekanan osmosis antara substansi dalam tubuhnya dengan lingkungan melalui sel yang permeabel. Semakin jauh perbedaan tekanan osmotik antara tubuh dan lingkungan, semakin banyak energi metabolisme yang dibutuhkan untuk melakukan osmoregulasi sebagai upaya adaptasi, hingga batas toleransi yang dimilikinya (Setyadi et al., 1997; Supriyatna, 1999). Akibatnya, energi yang diperoleh dari hasil metabolisme dalam tubuh yang seha- rusnya digunakan untuk pertumbuhan akan berkurang atau habis yang menyebabkan terhambatnya pertumbuhan udang. Ketersediaan pakan yang cukup serta daya dukung lingkungan yang baik akan mengefisienkan penggunaan energi sehingga dapat dimanfaatkan oleh udang untuk tumbuh dan mempertahankan sintasannya.

\section{Kualitas Air}

Kualitas air mempunyai peranan penting sebagai pendukung kehidupan dan pertumbuhan udang vaname. Hasil pengukuran beberapa peubah kualitas air pada media penelitian meliputi: suhu, $\mathrm{pH}, \mathrm{NH}_{3}, \mathrm{NO}_{3}, \mathrm{NO}_{2}$, dan $\mathrm{PO}_{4}$ pada setiap perlakuan selama penelitian disajikan pada Tabel 6.

Rendahnya kualitas air akan berakibat pada rendahnya sintasan, pertumbuhan, frekuensi ganti kulit, serta peningkatan jumlah mikroba atau jamur yang merugikan. Kualitas air yang layak untuk budidaya vaname adalah salinitas optimum 10- 25 ppt (toleransi 50 ppt); suhu $28^{\circ} \mathrm{C}-31^{\circ} \mathrm{C}$ (toleransi $16^{\circ} \mathrm{C}-36^{\circ} \mathrm{C}$ ); oksigen terlarut $>4 \mathrm{mg} / \mathrm{L}$ (toleransi maksimum 0,8 $\mathrm{mg} / \mathrm{L} ; \mathrm{pH} 7,5-8,2$; alkalinitas $120-150 \mathrm{mg} / \mathrm{L}$; amonia $<0,1 \mathrm{mg} / \mathrm{L}$; fosfat 0,5-1 mg/ L (Anonymous, 2003). Kisaran optimum nitrit untuk budidaya vaname berkisar 0,01-0,05 mg/ L (Adiwijaya et al., 2003), sedangkan untuk nitrat berkisar 0,4-0,8 mg/ L (Clifford, 1998). Berdasarkan hal tersebut maka kualitas air media untuk setiap perlakuan cukup baik dan layak dalam mendukung kehidupan udang vaname. 
Tabel 6. Kisaran kualitas air setiap perlakuan selama penelitian

Table 6. Water quality variation on each treatment during the experiment

\begin{tabular}{|c|c|c|c|c|}
\hline \multirow{2}{*}{$\begin{array}{c}\text { Peubah } \\
\text { Parameters }\end{array}$} & \multicolumn{4}{|c|}{$\begin{array}{l}\text { Kisaran kualitas air } \\
\text { Range water quality }\end{array}$} \\
\hline & $\mathbf{A}$ & B & C & $\mathbf{K}$ \\
\hline $\begin{array}{l}\text { Suhu } \\
\text { Temperature }\left({ }^{\circ} \mathrm{C}\right)\end{array}$ & $24.14-29.27$ & $24.02-29.22$ & $24.97-29.24$ & $24.01-30.06$ \\
\hline $\mathrm{pH}$ & 7.19-7.23 & $7.20-7.24$ & $7.10-7.25$ & 7.21-7.37 \\
\hline $\begin{array}{l}\mathrm{NH}_{3} \\
\text { Ammonia (ppm) }\end{array}$ & $0.5755-0.7762$ & $0.6003-0.7762$ & $0.5072-0.7762$ & $0.6398-0.7762$ \\
\hline $\begin{array}{l}\mathrm{NO}_{2} \\
\text { Nitrate (ppm) }\end{array}$ & $0.0035-0.0293$ & $0.0214-0.0468$ & $0.0199-0.0244$ & $0.0341-0.0494$ \\
\hline $\begin{array}{l}\mathrm{NO}_{3} \\
\text { Nitrite (ppm) }\end{array}$ & $0.0621-0.1499$ & $0.0665-0.1001$ & $0.0592-0.1935$ & $0.0410-0.0976$ \\
\hline $\begin{array}{l}\mathrm{PO}_{4} \\
\text { Phospate (ppm) }\end{array}$ & $0.0089-0.0448$ & $0.0162-0.0342$ & $0.0213-0.0824$ & $0.0342-0.0449$ \\
\hline
\end{tabular}

\section{KESIMPULAN}

\section{Kesimpulan}

Penambahan $\mathrm{KCl}$ sebagai sumber kalium 25- $75 \mathrm{mg} / \mathrm{L}$ pada media pemeliharaan udang vaname dapat meningkatkan kemampuan osmoregulasi dan mengurangi tingkat stres udang vaname yang dipelihara pada media air tawar. Performansi fisiologis udang vaname terbaik dengan tingkat osmotik, laju konsumsi oksigen dan konsentrasi glukosa darah minimum diperoleh pada perlakuan penambahan sumber kalium konsentrasi 55,05- 56,43 $\mathrm{mg} / \mathrm{L}$.

Meskipun telah diketahui bahwa udang vaname memiliki kisaran salinitas luas yang hidup di air payau, namun dengan aplikasi kalium pada media pemeliharaan memungkinkan udang vaname untuk dibudidayakan di air tawar. Budidaya udang vaname di air tawar merupakan salah satu solusi untuk menjawab permasalahan pembudidaya udang yang berada jauh dari sumber air laut.

\section{Saran}

Perlu penelitian lebih lanjut tentang penggunaan $\mathrm{KCl}$ sebagai sumber kalium dengan konsentrasi optimum yang telah diketahui pada budidaya udang vaname di air tawar skala besar di lapangan.

\section{UCAPAN TERIMA KASIH}

Penelitian ini dibiayai oleh DIPA BRPBAP Kementerian Kelautan dan Perikanan, Tahun Anggaran 2009. Kami mengucapkan terima kasih kepada Mat Fahrur, teknisi BRPBAP, atas bantuannya dalam penyiapan dan pelaksanaan penelitian dan $\mathrm{Hj}$. Sutrisyani atas bantuannya dalam menganalisis kualitas air di Laboratorium Air BRPBAP.

\section{DAFTAR ACUAN}

Adiwijaya, D., Sapto, P.R., Sutikno, E., Sugeng, \& Subiyakto. 2003. Budidaya udang vaname (Litopenaeus vannamei) sistem tertutup yang ramah lingkungan. Departemen Kelautan dan Perikanan. Balai Besar Pengembangan Budidaya Air Payau. Jepara, $29 \mathrm{hlm}$.

Allan, G.L. \& Magurire, G.B. 1991. Lethal levels of low dissolved oxygen and effects of short- term oxygen stress on subsequent growth of juvenile Penaeus monodon. Aquaculture, 94: 27-37.

Anggoro, S. 1992. Efek osmotik berbagai tingkat salinitas media terhadap daya tetas telur dan vitalitas larva udang windu, Penaeus monodon F. Disertasi. Pascasarjana IPB. Bogor, $230 \mathrm{hlm}$.

Anonim. 2003. Litopenaeus vannamei sebagai alternatif budidaya udang saat ini. PT 
Central Proteinaprima (Charoen Pokphand Group). Surabaya, $16 \mathrm{hlm}$.

Anonymous. 2008. Kalium atur keseimbangan elektrolit tubuh. http:/ / www.kompas.com/ $\mathrm{red} / \mathrm{xml} / 2008 / 07 / 07 / 22035499 /$ kalium. atur.keseimbangan.elektrolit.tubuh.

Barton, B.A. 1997. Stress in finfish: past, present and future-a historical perspective. In Fish Stress and Health in Aquaculture (Iwama, G.K., Pickering, A.D., Sumpter, J.P. \& Schreck, C.B., eds). Cambridge: Cambridge University Press, p. 1-33.

Begg, K. \& Pankhurst, N.W. 2004. Endocrine and metabolic responses to stress in a laboratory population of the tropical damselfish Acanthochromis polyacanthus. Journal of Fish Biology. 64: 133-145. doi: 10.1046/ j.1095-8649.2004.00290.xvan der Boon, J., Van den Thillart, G. E. E. \&Addink, A. D. F. (1991). The effects of cortisol administration on intermediary metabolism in teleost fish. Comparative Biochemistry and Physiology, 100 A: 47-53.

Batara, T. 2004. Tingkat konsumsi oksigen udang vaname (Litopenaeus vannamei) dan model pengelolaan oksigen pada tambak intensif. Skripsi. Program Studi Teknologi dan Manajemen Akuakultur. Fakultas Perikanan dan IImu Kelautan. IPB. Bogor, $27 \mathrm{hlm}$.

Boyd, C.E. 1990. Water quality management in pond aquaculture. Birmingham. Publishing Co. Alabama, p. 3-163.

Changbo, Z., Shuanglin, D., Fang, W., \& Guoqiang, H. 2004. Effects of $\mathrm{Na} / \mathrm{K}$ ratio in seawater on growth and energy budget of juvenile Litopenaeus vannamei. Aquaculture, 234: 485- 496.

Charmantier, G., Soyez, C., \& Aquacop. 1994. Effect of molt stage and hypoxia on osmoregulatory capacity in the penaeid shrimp Penaeus vannamei. J. Exp. Mar. Biol. Ecol., 178: 233-246.

Chen, J.C. \& Kou, T.T. 1998. Hemolymph acid-balance, oxyhemocyanin, and protein levels of Macrobrachium rosenbergii at different concentrations of dissolved oxygen. J. Crustac. Biol., 18: 437-441.

Cheng, W., Liu, C.H., \& Kuo, C.M. 2003. Effects of dissolved oxygen on hemolymph parameters of freshwater giant prawn, Macrobrachium rosenbergii (de Man). Aquaculture, 220: 843-856.

Clifford, H.C. 1998. Management of ponds stocked with blue shrimp Litopenaeus stylirostris. In print, Proceeding of the 1st latin American Congress on Shrimp Culture, Panama City. Panama, p. 101-109.

Connaughey, M. \& Zottoli, R. 1983. Introduction to Marine Biology. 4th edition. CV Mosby Company. London, 237 pp.

Cuzon, G., Lawrence, A., Gaxiol, G., Rosa, C., \& Guillaume, J. 2004. Nutrition of Litopenaeus vannamei reared in tanks or in ponds. Aquaculture, 235: 513-551.

Gamperl, A.K., Vijayan, M.M., \& Boutilier, R.G. 1994. Epinephrine, norepinephrine, and cortisol concentrations in cannulated seawater-acclimated rainbow trout (Oncorhynchus mykiss) following blackbox confinement and epinephrine injection. Journal of Fish Biology, 45: 313-324.

Hendradjat, E.A. \& Mangampa, M. 2007. Pertumbuhan dan sintasan udang vaname pola tradisional plus dengan kepadatan berbeda. Jurnal Riset Akuakultur, 2(2): 149155.

Jompa, H., Hidayat, S.S., Undu, M.C., \& Sulaeman. 2009. Tingkat konsumsi oksigen gelondongan udang pama (Penaeus semisulcatus) di Instalasi Tambak Percobaan Maranak. Prosiding Seminar Nasional Perikanan Indonesia 3-4 Desember 2009, Sekolah Tinggi Perikanan. Jakarta, p. 181-183.

Hepher, B. \& Pruginin, Y. 1981. Comercial fish farming. John Wiley \& Sons. New York, 261 pp.

Hill, A.D., Taylor, A.C., \& Strang, R.H.C. 1991. Physiological and metabolic responses of the shore crab Carcinus maenas (L.) during environmental anoxia and subsequent recovery. J. Exp. Mar. Biol. Ecol., 150: 3150.

Huynh, M.S. \& Fotedar, R. 2004. Growth, survival, hemolymph osmolality and organosomatic indices of the western king prawn (Penaeus laticulatus Kihinouye, 1896) reared at different salinities. Aquaculture, 234: 601- 614.

Karim, M.Y. 2007. Pengaruh salinitas dan bobot terhadap konsumsi kepiting bakau (Scylla serrata Forsskal). Jurnal Sains \& Teknologi, 7(2): 85-92.

Kumlu, M., Eroldogan, O.T., \& Saglamtimur, B. 2001. The effect of salinity and added substrates on growth and survival of Metapenaeus monoceros (Decapoda: Penaeidae) post- larvae. Aquaculture, 196: 177- 188. 
Kusmini, I.I., Wartono, H., \& Elinda P.S. 2006. Suhu optimum untuk laju pertumbuhan dan sintasan benih lobster air tawar Cherax quadricarinatus. Jurnal Riset Akuakultur, 1(1): 67-72.

Liao, I.C. \& Huang, H.J. 1975. Studies on the respiration of economic prawns in Taiwan. I. Oxygen consumption and lethal dissolved oxygen of egg up to young prawn of Penaeus monodon Fab. J. Fisheries Soc. Taiwan, 4(1): 33-50.

Linder, M.C. 1992. Nutritional Biochemistry and Metabolism. (Terjemahan.): Parakkasi A., 1992, Biokimia Nutrisi dan Metabolisme. UI Press. Jakarta, hIm. 201-214.

Lowe, C.J. \& Davison, W. 2005. Plasma osmolarity, glucose concentration and erythrocyte responses of two Antarctic nototheniid fishes to acute and chronic thermal change. Journal of Fish Biology, 67: 752766.

Lucu, C. \&Towle, D.W. 2003. $\mathrm{Na}^{+}+\mathrm{K}^{+}$- ATPase in Gill of Aquatic Crustacea. Comp Biochem Physiol., 135: 195- 214.

McEwen, B.S. 1998. Protective and Damaging Effects of Stress Mediators. N Engl J Med., 338: 171- 179.

McGraw, W.J., Davis, D.A., Teichert- Coddington, D., \& Rouse, D.B. 2002. Acclimation of Litopenaeus vannamei postlarvae to low salinity: influence of age, salinity endpoint, and rate of salinity reduction. J. of the World Aquaculture Society, p. 78- 84.

McGraw, W.J. \& Scarpa, J. 2003. Minimum environmental potassium for survival of Pasifik white shrimp Litopenaeus vannamei (Bonne) in fresswater. J. of Shellfish Research, 22(1): 263- 267.

Mommsen, T.P, Vijayan, M.M., \& Moon, T.W. 1999. Cortisol in teleosts: dynamics, mechanisms of action, and metabolic regulation. Rev. Fish Biol. Fish., 9: 211-268.

Morris, S. \& Butler, S.L. 1996. Hemolymph respiratory gas, acid-base, and ion status of the amphibious purple shore crab Leptograpsus variegatus (Fabricius) during immersion and environmental hypoxia. $J$. Crustac. Biol., 16: 253-266.

Ningharmanto. 2009. Kurang kalium dan kalsium, masalah di ginjal dan tulang. http:/ / www.ningharmanto.com /2009/09/ kurang-kalium- dan kalsium masalah- di- ginjaldan- tulang/.
Pickering, A.D. 1992. Rainbow trout husbandry: management of the stress response. Aquaculture, 100: 125-139.

Pickering, A.D. \& Pottinger, T.G. 1995. Biochemical effects of stress. In Biochemistry and Molecular Biology of Fishes, Vol. 5 (Hochachka, P.W. \& Mommsen, T.P., eds), p. 349-379. Amsterdam: Elsevier.

Pottinger, T.G., Carrick, T.R., Appleby, A., \& Yeomans, W.E. 2000. High blood cortisol levels and low cortisol receptor affinity: is the chub, Leuciscus cephalus, a cortisolresistant species?. General and Comparative Endocrinology, 120: 108-117.

Poernomo, A. 2004. Teknologi probiotik untuk mengatasi permasalahan tambak udang dan lingkungan budidaya. Makalah disampaikan pada simposium nasional pengembangan ilmu dan teknologi dalam budidaya di Semarang, 27- 29 Januari 2004. Semarang, $24 \mathrm{hlm}$.

Riley, J.P. \& Chester, R. 1971. Introduction to Marine Chemistry. Academic Press. London, $465 \mathrm{pp}$.

Saoud, I.P., Davis, D.A., \& Rouse, D.B. 2003. Suitability studies of inland well waters for Litopenaeus vannamei culture. Aquaculture, 217: 373- 383.

Setyadi, I., Azwar, Z.I., Yunus, \& Kasprijo. 1997. Penggunaan jenis pakan alami dan pakan buatan dalam pemeliharaan larva kepiting bakau Scylla serrata. J. Pen. Perik. Indonesia, VII(1): 73- 77.

Supriyatna, A. 1999. Pemeliharaan larva rajungan Portunus pelagicus dengan waktu pemberian pakan yang berbeda. Prosiding Seminar Nasional Puslitbangkan bekerjasama dengan JICA ATA, 379: 168172.

Tahe, S. 2008. Pengaruh starvasi ransum pakan terhadap pertumbuhan, sintasan, dan produksi udang vaname (Litopenaeus vannamei) dalam wadah terkontrol. Jurnal Riset Akuakultur, 3(3): 401- 412.

Taqwa, F.H., Djokosetiyanto, D., \& Affandi, R. 2008. Pengaruh penambahan kalium pada masa adaptasi penurunan salinitas terhadap performa pascalarva udang vaname (Litopenaeus vannamei). Jurnal Riset Akuakultur, 3(3): 431- 436.

Teskeredzic, E., Teskeredzic, Z., Tomec, M., \& Modrusan, Z. 1989. A comparison of the growth performance of Rainbow Trout 
(Salmo gairdneri) in fresh and brachish water in Yugoslavia. Aquaculture, 77: 1- 10. Amsterdam: Elsevier.

Vijayan, M.M. \& Moon, T.W. 1992. Acute handling stress alters hepatic glycogen metabolism in food- deprived rainbow trout (Oncorhynchus mykiss). Canadian Journal of Fisheries and Aquatic Sciences, 49: 22602266.

Vijayan, M.M., Pereira, C., Grau, E.G., \& Iwama, G.K. 1997. Metabolic responses associated with confinement stress in tilapia: the role of cortisol. Comparative Biochemistry and Physiology. 116C: 89-95.

Waring, C.P., Stagg, R.M., \& Poxton, M.G. 1996. Physiological responses to handling in the turbot. Journal of Fish Biology, 48: 161-173.

Waser, W.P. \& Heisler, N. 2004. Oxygen delivery to the fish eye: blood flow in the pseudobranchial artery of rainbow trout (Oncorhynchus mykiss). Fish Physiology and Biochemistry, 30: 77-85.

Wedemeyer, G.A., Barton, B.A., \& McLeay, D.J. 1990. Stress and acclimation. In Methods for Fish Biology (Schreck, C.B. \& Moyle, P.B., eds), Bethesda, MD: American Fisheries Society, p. 451-489.

Wells, R.M.G. \& Weber, R.E. 1990. The spleen in hypoxic and exercised rainbow trout. Journal of Experimental Biology, 150: 461-466.

Wendelaar, B.S.E. 1997. The stress response in ûsh. Physiol. Reviews, 77: 591-625.

Zimmer, K. 1996. How Low Dissolved Oxygen Conditions Affect Marine Life In Long Island Sound. New York Sea Grant Extension Program for the Long Island Sound Study. http:// longislandsoundstudy.net/ wp- content/ uploads/ 2010/ 03/ lodo.pdf. 